\title{
Pelatihan Pembuatan Soal Matematika Berbasis CTL dan Penggunaan Aplikasi Pembelajaran Online di SMA Adabiah Padang
}

\author{
Hafizah Delyana1, Ainil Mardiyah², Ali Asmar ${ }^{3}$ \\ hafizahdelyana@gmail.com¹,m.ainil@yahoo.com², aliasmar.sumbar@gmail.com³ \\ 1,2Universitas PGRI Sumatera Barat \\ ${ }^{3}$ Universitas Negeri Padang
}

\begin{tabular}{ll}
\hline Article History: & Abstract: Mathematics is one of the subjects that students find \\
Received: $31-12-2021$ & difficult, especially for the mastery of realistic questions or in \\
Revised: $25-01-2022$ & the form of story problems. These questions are included in \\
Accepted: $25-01-2022$ & CTL-based or contextual questions. Contextual problem is a \\
& question that links the material with real-world situations and \\
encourages students to make connections between the & material they learn and its application in their daily lives. \\
& Mathematics teacher at SMA Adabiah has difficulty designing \\
CTL-based math problems. In addition, during this pandemic, & teachers had difficulty giving questions online because face-to- \\
& face was not possible. For this reason, teachers are required to \\
have creativity so that learning can be understood by students. & Mathematics teachers are given training that supports this. The \\
training that will be provided is creating an online test using \\
kahoot and quizzes. Teachers who take part in the training are \\
expected to be able to motivate and evaluate students' ability to \\
work on contextual questions even though they are carried out \\
online.
\end{tabular}

\section{Pendahuluan}

Perkembangan teknologi informasi dan komunikasi di era Industri 4.0 telah memiliki pengaruh yang besar terhadap proses pengajaran dan pembelajaran. Kemudahan akses teknologi telah digunakan oleh para pengajar untuk meningkatkan kualitas pendidikan (Khusniyah \& Hakim, 2019). Dunia pendidikan saat ini sedang mengalami kejadian yang sangat luar biasa. Pandemi Covid-19 berpengaruh sangat luas bagi para peserta dan institusi pendidikan. Ujian Nasional ditiadakan, dan konsep "belajar dari rumah" digaungkan, dan pada akhirnya memaksa para pelaku pendidikan untuk menerapkan pembelajaran dalam jaringan (daring). Sistem pendidikan kita harus siap melakukan lompatan untuk melakukan transformasi pembelajaran daring bagi semua siswa dan oleh semua guru. Kita memasuki era baru untuk membangun kreatifitas, mengasah skill siswa, dan peningkatan kualitas diri dengan perubahan sistem, cara pandang dan pola interaksi kita dengan teknologi.

Pembelajaran daring memiliki banyak keunggulan. Oleh karena itu, seharusnya pembelajaran daring tidak sekedar menjadi pengganti dari pembelajaran konvensional (tatap muka), tetapi kelak bisa berjalan beriringan, berkelanjutan, dengan pembelajaran konvensional (Rigianti, 2020). Momentum penanggulangan Covid-19 saat ini adalah saat 
yang tepat bagi pemerintah, yayasan, dan berbagai institusi pendidikan meningkatkan kemampuan agar pembelajaran daring bisa berkelanjutan, dan tidak kemudian berhenti atau ditiadakan setelah pandemi Covid-19 berakhir. Kunci efektivitas dari sistem pembelajaran daring adalah bagaimana seorang guru tetap kreatif untuk menyajikan pembelajaran daring secara menyenangkan dan mudah dimengerti sehingga para siswa tidak merasa bosan dan tetap produktif di rumah (Handarini, 2020). Guru dituntut untuk inovatif dalam menggunakan pembelajaran dengan model daring (Anugrahana, 2020).

Dalam proses pembelajaran, guru perlu membiasakan siswa memecahkan permasalahan sendiri dan menemukan hubungan materi yang dipelajari dengan kehidupan nyata sehingga pembelajaran menjadi lebih bermakna dan nyata. Ketidakberhasilan peserta didik untuk memecahkan persoalan dalam pembelajaran dimungkinkan sebagai akibat pembelajaran yang dilaksanakan selama ini menggunakan strategi belajar mengajar dengan cara konvensional yaitu aktivitas di kelas didominasi oleh guru, maka dari itu, guru harus pandai memilih metode, pendekatan, model pembelajaran dan teknik mengajar yang sesuai dengan materi yang akan diajarkan. Guru masih memanfaatkan buku-buku teks yag tersedia di perpustakaan sekolah, dimana siswa semakin jenuh dan menganggap matematika adalah pelajaran yang membosankan. Sitorus (2013) juga mengatakan bahwa belajar matematika merupakan suatu proses aktif yang sengaja untuk memperoleh pengetahuan baru dalam mengembangkan struktur-struktur yang terdapat dalam bahasan matematika, serta mencari hubungannya untuk mendapat suatu pengertian dan mengaplikasikan konsep dalam situasi yang nyata, sehingga arah belajar matematika umumnya menuju kepengabstrakan yang semakin kompleks. Matematika juga berkaitan dengan ide-ide atau gagasan-gagasan.

Menurut Surata \& Marhaeni (2019) dalam proses pembelajaran sebaiknya siswa tidak hanya dianggap pasif sebagai penerima informasi, akan tetapi dipandang sebagai yang memiliki potensi untuk berkembang. Beberapa topik matematika sangat erat kaitannya dengan kehidupan sekitar siswa, sehingga penggunaan pendekatan CYL sangat tepat digunakan. Penggunaan soal berbasis CTL bertujuan membantu guru dalam mengaitkan antara materi yang diajarkan dengan situasi dunia nyata siswa dan mendorong siswa membuat kaitan antara pengetahuan yang dimiliki dengan penerapannya dalam kehidupan. Melalui soal berbasis CTL, siswa bukan lagi penerima informasi atau fakta dengan menghapal sejumlah konsep tetapi dapat menemukan sendiri pengetahuan, konsep, teori dan kesimpulan. Hal ini sejalan dengan pendapat (Refianti et al., 2019) bahwa penggunaan konteks yang disesuaikan dengan lingkungan siswa dapat mempermudah siswa memahami suatu permasalahan matematika yang disajikan. Hal ini juga didukung oleh Rizki \& Amir (2017) yang menyatakan bahwa soal berbasis CTL adalah soal yang mengaitkan isi 
pelajaran dengan lingkungan sekitar siswa atau dunia nyata siswa, sehingga akan membuat pembelajaran lebih bermakna (meaningful learning), karena siswa mengetahui pelajaran yang diperoleh di kelas akan bermanfaat dalam kehidupan sehari-hari.

Dari observasi dan wawancara pengabdi dengan guru matematika di SMA Adabiah, diperoleh informasi bahwa masih banyak siswa yang kurang mengerti dalam menyelesaikan soal cerita tentang materi ukuran pemusatan data. Siswa kurang memahami maksud dari soal cerita. Sehingga tidak bisa membedakan mana yang diketahui, ditanya, dan penyelesaian dari soal cerita tersebut. Hal ini dapat dilihat dari hasil belajar siswa yang rendah, yaitu dengan rata-rata 6,2. Menurut Budhi dalam (Jusmaini, 2016) soal cerita adalah soal yang berbentuk cerita tentang sesuatu hal yang berkaitan dengan kehidupan seharihari.

Menurut Malyana (2020) masa Covid-19 menuntut guru sebagai tenaga pendidik, tetap dituntut menjalankan pendidikan di sekolah. Pembelajaran diharuskan tetap berlangsung agar pendidikan terjamin. Tugas pokok dan fungsi guru yang melekat tetap akan dilaksanakan, karena guru diharapkan menjalankan pendidikan dan pembelajarannya, maka guru dituntut kreatifitasnya sebagai fasilitator dalam pembelajaran. Guru-guru matematika di sekolah tersebut belum bisa menggunakan aplikasi untuk membuat kuis secara online, sementara kemampuan matematika siswa tetap harus dilatih dan ditingkatkan. Untuk melakukan evaluasi kemampuan siswa diperlukan suatu aplikasi online yang harus dipahami oleh guru. Tidak semua aplikasi yang ada sesuai dengan kebutuhan pembelajaran, akan tetapi guru-guru bisa memilih aplikasi yang cocok dengan mata pelajaran tersebut. Untuk itu guru-guru matematika di SMA Adabiah Padang khususnya harus dibekali dengan pengetahuan tentang penggunaan aplikasi terutama dalam penyelesaian soal-soal olimpiade matematika dalam bentuk kuis.

Pembelajaran online menghubungkan pembelajar (peserta didik) dengan sumber belajarnya (database, pakar/instruktur, perpustakaan) yang secara fisik terpisah atau bahkan berjauhan namun dapat saling berkomunikasi, berinteraksi atau berkolaborasi (secara langsung/synchronous dan secara tidak langsung/asynchronous) (Rosali et al., 2020). Pemberian kuis secara online adalah salah satu bentuk pembelajaran daring. Pemberian kuis merupakan salah satu cara untuk melatih siswa melakukan refleksi terhadap materi yang baru diajarkan sekaligus mengevaluasi penguasaan materi, sehingga membantu siswa membangun kemampuan melakukan asesmen diri atas tingkat pemahaman yang dicapai. Untuk melaksanakan kuis secara online dibutuhkan sebuah media atau aplikasi.

Salah satu nya adalah media kahoot dan quizizz. Dengan menggunakan aplikasi 
tersebut, guru bisa mengetes pemahaman siswa melalui kuis yang sangat menyenangkan. Teknologi pembelajaran jarak jauh yang satu ini memang sangat disarankan digunakan, karena bisa menjadi salah satu cara untuk membuat belajar tidak membosankan. Selain itu, aplikasi ini juga cocok digunakan dalam masa belajar di rumah.

Aplikasi ini juga dapat digunakan sebagai media untuk pembelajaran matematika. Guru dapat memberikan soal kepada siswa dan diselesaikan oleh siswa pada waktu yang sesuai dengan yang sudah ditetapkan. Menurut Putria et al. (2020) beberapa kelebihan dari pembelajaran daring yaitu adanya keluwesan waktu dan tempat belajar, misalnya belajar dapat dilakukan si kamar, ruang tamu dan sebagainya serta waktu yang diseseuaikan misalnya pagi, siang, sore atau malam. Dapat mengatasi permasalahan mengenai jarak, misalnya peserta didik tidak harus pergi ke sekolah dahulu untuk belajar. Tidak ada batasan dan dapat mencakup area yang luas. Sehingga guru bisa mengevaluasi kemampuan siswa dengan materi yang sudah diberikan. Termasuk melatih siswa-siswa untuk mempersiapkan diri dalam kompetisi atau kegiatan olimpiade yang diadakan oleh pemerintah maupun pihak lainnya.

\section{Metode}

Berdasarkan masalah mitra, maka solusi yang ditawarkan adalah dengan mengadakan pelatihan pembuatan Kuis Online. Pelatihan diadakan selama 3 kali pertemuan dalam jangka waktu 1 minggu. Pelatihan ini dilaksanakan dengan metode bimbingan melalui diktat. Hal ini bertujuan untuk melatih guru mampu membuat soal berbasis CTL disertai aplikasi pembelajaran yang berbasis IT menggunakan aplikasi Kahoot dan Quizizz. Langkah-langkah pelaksanaan kegiatan pengabdian ini adalah sebagai berikut:

1. Tahap Persiapan: Merancang modul pelatihan, mempersiapkan peralatan penunjang kegiatan, mengurus administrasi seperti perizinan melakukan kegiatan baik dari PT maupun dari sekolah mitra, memberikan pelatihan kepada mahasiswa yang terlibat pada kegiatan pelatihan, menyepakati jadwal pelaksanaan kegiatan pelatihan dengan mitra.

2. Tahap Pelaksanaan: Melaksanakan kegiatan pelatihan sebanyak 3 kali pertemuan pada guru-guru matematika di SMA Adabiah Padang.

3. Tahap Akhir: Pembuatan laporan Jika guru sudah mampu memahami cara membuat kuis pembelajaran berbasis IT, maka diharapkan guru mampu mengaplikasikannya dalam proses pembelajaran.

Sebelum pelatihan dilaksanakan terlebih dahulu tim dosen membuat soal statistika berbasis CTL yang diajarkan pada kelas XI yang digunakan sebagai bahan dalam mengikuti proses pelatihan. Pelakasanaan sosialisasi ini dilakukan secara daring menggunakan platform Zoom. 


\section{Pembahasan}

Salah satu materi pelajaran yang dapat memberi makna melalui pengalaman belajar siswa adalah Statistika. Materi tersebut berkaitan dengan kehidupan sehari-hari. Statistika merupakan materi yang termuat dalam Kompetensi Dasar (KD) mata pelajaran matematika SMA Adabiah di kelas $X$ yang harus dicapai oleh siswa melalui pengalaman belajar. Pembelajaran mengenai statistika sebaiknya diawali dengan menghadirkan permasalahan nyata untuk memberikan stimulus kepada siswa agar siswa mampu berpikir kreatif dan dapat menemukan sendiri solusi dari masalah yang dihadapi. Menurut Santoso (2017), matematika dapat dianggap sukar dilihat dari hasil belajar yang bervariasi setelah proses pembelajaran dilaksanakan. Selain itu dalam proses pembelajaran pun matematika tidak bisa dipahami hanya dengan membaca materi atau mendengarkan penjelasan dari guru semata, harus disertai dengan latihan soal.

Berikut salah satu contoh soal statistika berbasis CTL yang dirancang oleh guru matematika di SMA Adabiah:

\section{Seandainya ada tiga orang anak mendapatkan uang belanja dari orangtuanya, misalnya Andi mendapatkan uang Rp 10.000; Mimi mendapatkan Rp 20.000 dan Syanial memiliki Rp 15.000, maka dengan mudah dapat ditentukan bahwa mereka rata-rata mendapatkan uang $R p$ 15.000. Dalam hal ini dapat dimisalkan uang yang didapat Andi sebagai $x_{1}=R p$ 10.000,-; uang yang didapat Mimi sebagai $x_{2}=R p 20.000,-$ dan Syania sebagai $x_{3}=$ Rp 15.000,- . Berapakah rata- rata uang yang mereka peroleh?}

Soal di atas dirancang oleh guru dan sangat erat kaitannya dengan keseharian siswa. Soal ini akan membantu siswa dalam memahi konsep materi. Siswa juga akan termotivasi dalam menyelesaikan soal-soal seperti di atas.

Pembelajaran online merupakan inovasi pendidikan untuk menjawab tantangan akan ketersediaan sumber belajar yang variatif. Keberhasilan dari suatu model ataupun media pembelajaran tergantung dari karakteristik peserta didiknya (Dewi, 2020). Kegiatan pengabdian ini berlangsung sebanyak tiga kali pertemuan. Pada pertemuan pertama kegiatan yang dilakukan yaitu pengenalan aplikasi Kahoot dalam pembuatan kuis online. Selanjutnya pada pertemuan kedua, kegiatan yang dilakukan yaitu penyajian materi tentang soal-soal olimpiade yang mengasah keterampilan kemampuan pemecahan masalah matematis. Pada pertemuan terakhir guru melakukan latihan pembuatan kuis online menggunakan aplikasi Kahoot tentang soal-soal olimpiade. Kebutuhan koneksi internet dalam penggunaan aplikasi ini menjadi hal yang sangat penting dalam pelaksanaan pembelajaran daring (Rigianti, 2020). 
Beberapa peralatan harus dipersiapkan sebelum proses evaluasi pembelajaran dilakukan dengan menggunakan, salah satunya adalah menggunakan Kahoot agar memperoleh interaksi evaluasi optimal yaitu:

a. Peralatan yang harus dipersiapkan oleh guru adalah Overhead Projector dan Layar

b. Guru juga membawa smartphone, tablet atau Laptop

c. Sekolah menyiapkan koneksi internet kuat dan reliabel. Jika prasyarat perlengkapan di atas telah terpenuhi, maka dapat dilakukan proses berikutnya merupakan tahapan pembuatan quiz pada kahoot. Berikut tampilan awal mulai mendaftar Kahoot.

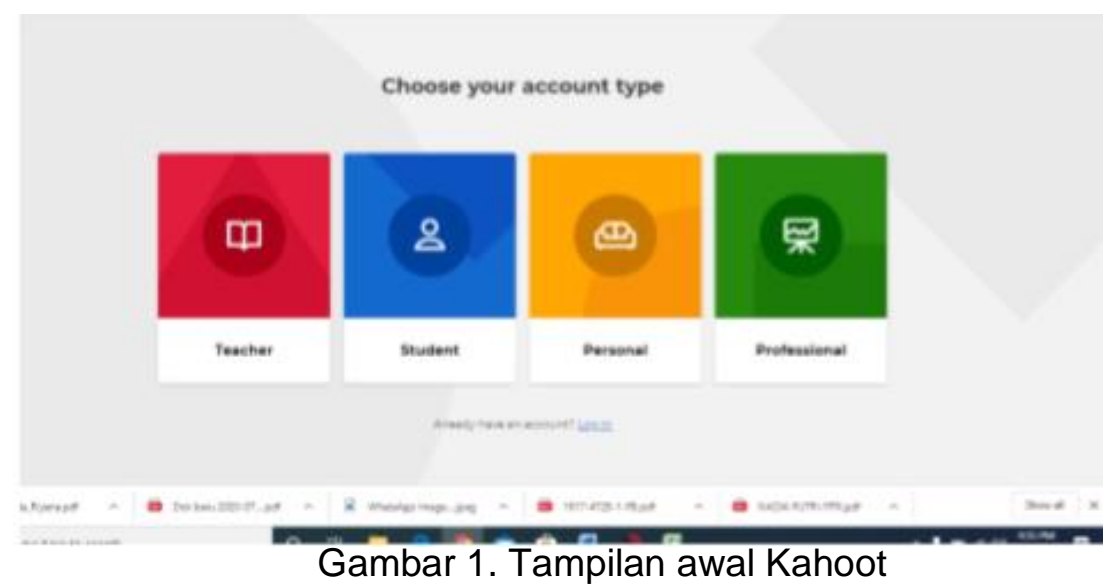

Pada Gambar 1, seorang guru akan memilih/ mengklik "teacher". Sedangkan siswa mengklik "student". Pada tahapan ini ada dua metode untuk membuat kegiatan evaluasi yaitu menggunakan komputer dan smartphone. Jika menggunakan komputer, tahapan dapat dilakukan sesuai langkah-langkah berikut ini:

a. Ketik kahoot.com dan log in menggunakan akun kahoot, jika belum silahkan mendaftar melalui tombol sign up for free dan mendaftar dengan menggunakan akun gmail atau facebook.

b. Buka kahoot sesuai dengan yang diinginkan, click quiz untuk membuat pertanyaan tipe multiple choice.

c. Setiap pertanyaan dapat di setting lamanya waktu untuk menjawab dan besar skor yang didapat bergantung tingkat kesulitan pada soal.

d. Tahap akhir, setiap soal di kahoot dapat di tambahkan gambar dan video untuk menambah kontek yang menarik atau memberikan bantuan untuk menjawab soal.

e. Jika sudah selesai, copy link atau dapatkan PIN (kombinasi angka) untuk mengkases quiz yang telah dibuat. Untuk para peserta didik, tidak perlu mendaftar akun seperti ketika masuk sebagai guru. Hanya membutuhkan PIN atau LINK yang telah didapatkan dari akun guru ketika membuat quiz.

Untuk memainkan kahoot ini hanya tiga tahap: 
a. Jalankan kahoot dari akun sebagai guru dan tampilkan pada layar, kemudian klik play dan pilih mode antara klasik (perorangan = 1 alat untuk 1 orang) atau mode tim (1 alat untuk beberapa orang). Tunggu hingga muncul pin seperti pada gambar 2 berikut ini.

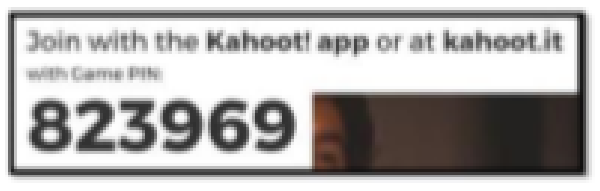

Gambar 2. Tampilan pin Kahoot

b. Peserta didik dapat mengakses langsung kahoot.it dan join dengan menggunakan PIN yang muncul. Peserta didik diharapkan menyiapkan nama panggilan atau nama tim jika digunakan pada mode grup.

c. Tunggu hingga muncul nama peserta didik di monitor utama guru. Kemudian klik mulai.

Selama kegiatan PPM ini, para guru tampak terlihat sangat antusias dan interaktif. Berdasarkan hasil wawancara tim PPM diperoleh informasi bahwa para guru memiliki ketertarikan untuk dapat memperoleh pelatihan lanjutan dari kegiatan yang telah dilakukan saat ini. Sehingga mereka dapat mengaplikasikan Kahoot ini pada bentuk soal-soal dengan tipe yang lain. Banyak pertanyaan muncul terutama pada saat praktek penggunaan Kahoot. Hasil pengamatan menunjukkan bahwa beberapa guru masih mengalami kesulitan dalam mengoperasikan Kahoot. Sebagian guru telah mengenal aplikasi ini sedangkan sisanya baru mengenal Kahoot, sehingga mereka masih terlihat kesulitan dalam pengoperasian aplikasi ini tanpa didampingi ataupun tanpa melihat petunjuk yang ada pada modul. Sehingga memakan waktu yang cukup lama untuk dapat mengerjakan satu soal. Selain itu, Kendala yang sering kali muncul dalam kegiatan ini adalah bahwa para guru terkadang menanyakan sesuatu hal atau materi yang sulit diimplementasikan dengan Kahoot. Sehingga dibutuhkan penjelasan yang jelas dari tim untuk dapat memberikan arahan sehingga tidak terjadi kekeliruan dalam penggunaan Kahoot di pembelajaran matematika. 


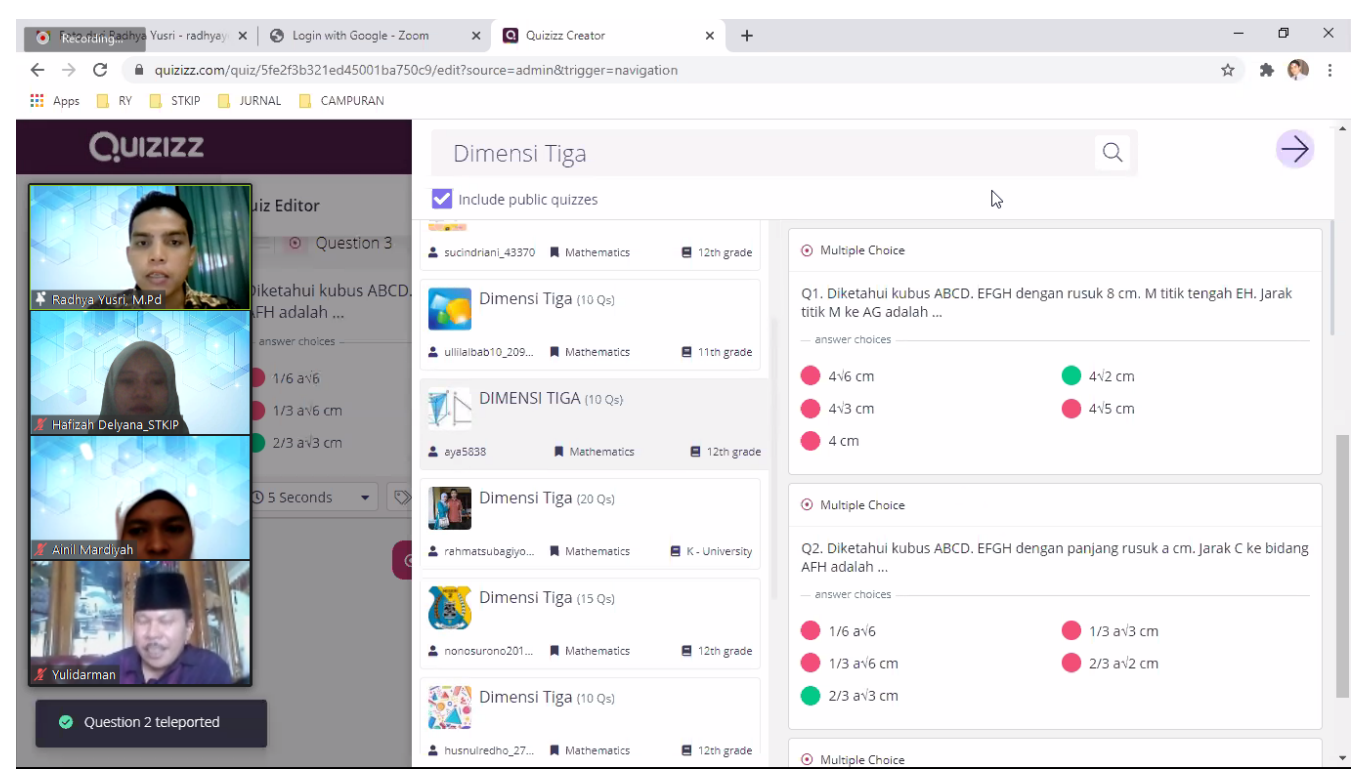

Gambar 3. Penyajian materi kepada guru-guru di SMA Adabiah Padang

Berdasarkan hasil wawancara dengan beberapa orang guru yang terlibat pelatihan menggunakan aplikasi Kahoot ini, menyatakan bahwa aplikasi ini sangat cocok untuk para peserta didik. Pada awal pembelajaran daring, materi hanya diberikan melalui Microsoft Word kemudian siswa membaca, sehingga lama-lama siswa merasa bosan. Ketika guru menyuguhkan pembelajaran daring melalui video, siswa sangat antusias dalam mengikuti pembelajaran. Apalagi bila mengerjakan latihan soal berupa kuis melalui aplikasi Kahoot, siswa sangat antusias karena mereka bisa melihat langsung jawaban yang benar dan juga mereka juga dapat melihat langsung skor atau hasil dari pekerjaan mereka. Zoom Meeting hanya sesekali dilaksanakan karena mengingat tidak semua siswa dapat mengaksesnya terlebih ada beberapa siswa yang terkendala sinyal dan penggunakan aplikasi Zoom juga dikhawatirkan banyak menghabiskan kuota data peserta didik. Selama pembelajaran daring dilaksanakan, hal yang paling sulit dicapai dalam indikator keaktifan belajar siswa adalah ikut serta dalam pemecahan masalah pada materi pembelajaran yang sedang dibahas. Tetapi berdasarkan wawancara dari ke empat siswa tersebut, mereka selalu ikut serta dalam pemecahan masalah agar permasalahan dapat terpecahkan secara bersama-sama (Naziah et al., 2020).

Menurut Sadikin \& Hamidah (2020) peserta didik merasa lebih nyaman dalam mengemukakan gagasan dan pertanyaan dalam pembelajaran daring. Mengikuti pembelajaran dari rumah membuat mereka tidak merasakan tekanan psikologis dari teman sebaya yang biasa mereka alami ketika mengikuti pembelajaran tatap muka. Hal ini juga didukung oleh Sofyana \& Rozaq (2019) yang menyatakan bahwa penerapan pembelajaran online dinilai efektif apabila diterapkan karena pembelajaran tidak dibatasi ruang dan waktu, yang tidak mewajibkan mahasiswa untuk selalu belajar di dalam ruang kelas dengan segala 
peraturan yang kaku. Meskipun demikian, menurut Anugrahana (2020) pembelajaran daring juga memiliki kelemahan yaitu kurang maksimalnya keterlibatan siswa. Keterlibatan siswa yang dimaksud dapat dilihat dari hasil keterlibatan siswa dalam mengikuti pembelajaran daring secara penuh dari awal pembelajaran sampai akhir pembelajaran.

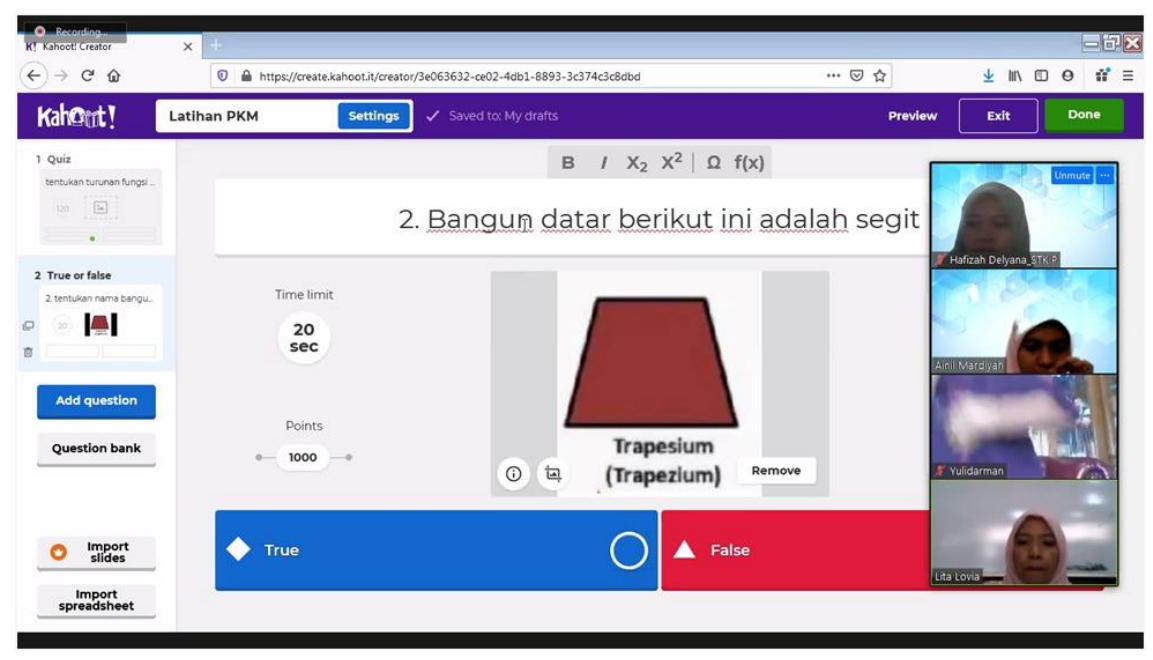

Gambar 4. Foto dokumentasi pengabdian

\section{Kesimpulan}

Hal yang dapat disimpulkan dari hasil kegiatan PPM ini adalah

1. Soal Berbasis CTL mampu meningkatkan kemampuan pemecahan masalah siswa, sehingga siswa mudah dalam memahami konsep.

2. Kahoot dan Quizizz, sebagai media pembelajaran berbasis digital game based learning dapat dioptimalkan untuk meningkatkan motivasi dan kemandirian peserta didik dan dimanfaatkan untuk memudahkan proses evaluasi pembelajaran. Untuk pengembangan disisi keceradasan intelektual peserta didik, konten kahoot dan Quizizz dapat dibuat untuk mendorong peserta didik untuk mendalami setiap materi yang diajarkan Kahoot dapat dimanfaatkan tidak hanya untuk pembelajaran di dalam kelas, namun dapat dimanfaatkan sebagai tugas belajar yang dikerjakan diluar kelas.

\section{UcapanTerimakasih}

Ucapan terimakasih disampaikan pada LPPM Universitas PGRI Sumatera Barat yang telah mendukung pelaksanaan kegiatan pengabdian dan pihak SMA Adabiah Padang yang telah memberikan izin serta membantu menyediakan tempat pelaksanaan kegiatan. Selain itu, disampaikan terimakasih kepada pihak-pihak yang telah banyak membantu sehingga kegiatan pengabdian ini dapat berjalan dengan baik. 


\section{Daftar Pustaka}

Anugrahana, A. (2020). Hambatan, Solusi dan Harapan: Pembelajaran Daring Selama Masa Pandemi Covid-19 Oleh Guru Sekolah Dasar. Jurnal Scholaria, 10(3), 282-289.

Dewi, W. A. F. (2020). Dampak COVID-19 terhadap Implementasi Pembelajaran Daring di Sekolah Dasar. Edukatif: Jurnal Ilmu Pendidikan, 2(1), 55-61. https://doi.org/10.31004/edukatif.v2i1.89

Handarini, O. I. (2020). Pembelajaran Daring Sebagai Upaya Study From Home (SFH) Selama Pandemi Covid 19 Oktafia. Jurnal Pendidikan Administrasi Perkantoran (JPAP), 8(3), 496-503. https://doi.org/10.1093/fampra/cmy005

Jusmaini, J. (2016). Upaya Peningkatan Hasil Belajar Soal Cerita Melalui Pendekatan Contextual Teaching and Learning (CTL) Pada Siswa Kelas III Sekolah Dasar Negeri 07 Batang Anai. Jurnal Konseling Dan Pendidikan, 4(2), 67. https://doi.org/10.29210/16500

Khusniyah, N. L., \& Hakim, L. (2019). Efektivitas Pembelajaran Berbasis Daring: Sebuah Bukti Pada Pembelajaran Bahasa Inggris. Jurnal Tatsqif, 17(1), 19-33. https://doi.org/10.20414/jtq.v17i1.667

Malyana, A. (2020). Pelaksanaan Pembelajaran Daring dan Luring Dengan Metode Bimbingan Berkelanjutan Pada Guru Sekolah Dasar Di Teluk Betung Utara Bandar Lampung. Jurnal Ilmiah Pendidikan Dasar Indonesia, 2(1), 67-76.

Naziah, S. T., Maula, L. H., \& Sutisnawati, A. (2020). Analisis Keaktifan Belajar Siswa Selama Pembelajaran Daring Pada Masa Covid-19 Di Sekolah Dasar. Jurnal Paedagogy: Jurnal Penelitian Dan Pengembangan Pendidikan, 7(2), 109-120.

Putria, H., Maula, L. H., \& Uswatun, D. A. (2020). Analisis Proses pembelajaran Dalam Jaringan (DARING) Masa Pandemi COVID-19 pada Guru Sekolah Dasar. Jurnal Basicedu, 4(4), 861872. https://doi.org/10.31004/basicedu.v4i4.460

Refianti, R., Marisa Z, M. Z., \& Mandasari, N. (2019). Pengembangan Lembar Kerja Siswa (LKS) Menggunakan Contextual Teaching and Learning (CTL) Berbasis Kota Lubuklinggau. Jurnal $\begin{array}{llll}\text { Pendidikan Matematika (JUDIKA EDUCATION), } & \text { 2(2), }\end{array}$ https://doi.org/10.31539/judika.v2i2.863

Rigianti, H. A. (2020). Kendala Pembelajaran Daring Guru Sekolah Dasar Di Di Kabupaten Banjarnegara. Elementary School, 7(2), 297-302.

Rizki, L. M., \& Amir, Z. M. (2017). Pengembangan Lembar Kerja Siswa Berbasis Pendekatan Contextual Teaching And Learning Untuk Memfasilitasi Kemampuan Koneksi Siswa SMP/MTs. Indonesian Digital Journal of Mathematics and Education, 4(6), 400-409. http://idealmathedu.p4tkmatematika.org

Rosali, E. S., Pendidikan, J., \& Universitas, G. (2020). Aktifitas Pembelajaran Daring Pada Masa Pandemi Covid -19 Di. Geography Science Education Journal (GEOSEE), 1(1), 21-30.

Sadikin, A., \& Hamidah, A. (2020). Pembelajaran Daring di Tengah Wabah Covid-19. Biodik, 6(2), 109-119. https://doi.org/10.22437/bio.v6i2.9759

Sitorus, R. (2013). Meningkatkan Hasil Belajar Siswa Dengan Pendekatan Contextual Teaching And Learning (Ctl) Dalam Penyelesaian Soal Cerita Matematika SD. Paper Dosen Jurusan PPSD Prodi PGSD FIP Unimed.

Sofyana, L., \& Rozaq, A. (2019). Pembelajaran Daring Kombinasi Berbasis Whatsapp Pada Kelas Karyawan Prodi Teknik Informatika Universitas Pgri Madiun. Jurnal Nasional Pendidikan Teknik Informatika (JANAPATI), 8(1), 81. https://doi.org/10.23887/janapati.v8i1.17204

Surata, I. K., \& Marhaeni, I. G. A. A. N. D. (2019). Pendekatan Contextual Teaching And Contextual Teaching And Learning (Ctl) Berbasis Lembar Kerja Peserta Didik (Lks) Untuk Meningkatkan Aktivitas Belajar Biologi Contextual Teaching and Learning (CTL) Approaches Based On Student Worksheet to Improve Biolog. Jurnal Pendidikan Biologi, 4(2), 114-121. http://jurnal.unsil.ac.id/index.php/bioed/article/view/1135/824 